\title{
既存コンクリート部材におけるコンクリート目荒らし面のせん断応力伝達と 微小面の接触応力に基づく力学モデル
}

\section{SHEAR STRESS TRANSFER OF ROUGHENED CONCRETE FOR EXISTING R/C MEMBERS AND MECHANICAL MODEL BASED ON CONTACT STRESS ON LOCAL SURFACE}

\author{
磯崎翼*1, 高 瀬 裕 也*2, 阿部隆 英*3, \\ 坂本啓太 ${ }^{* 4}$, 樋 渡 健 ${ }^{* 5}$, 香取 慶一 ${ }^{* 6}$ \\ Tsubasa ISOZAKI, Yuya TAKASE, Takahide ABE, \\ Keita SAKAMOTO, Takeshi HIWATASHI and Keiichi KATORI
}

\begin{abstract}
When buildings undergo seismic retrofitting, reinforcing members are connected to existing members by roughening the concrete surfaces and installing new anchors. In the Japanese guidelines pertaining to the seismic retrofitting of structures, no standards are provided for concrete roughening. Therefore, we conducted shear loading tests and measurements of the roughened surfaces were taken. Then, mechanical models of the roughened concrete surfaces were developed based on a constitutive law for cracked concrete surfaces. Using the results, a model is proposed from which shear stress-shear displacement relations as well as normal stress-shear displacement relations can be reasonably estimated.
\end{abstract}

Keywords : Shear stress transfer, Concrete roughening, Seismic retrofitting, Shape measurement せん断応力伝達，コンクリート目荒らし，而震補強，形状測定

\section{1. はじめに}

近年，現行の耐震基準を満足できていない既存コンクリート構造 物は，補強部材（鉄骨ブレースなど）を設置することで，耐震性能 の向上が図られている。既存コンクリート構造物を耐震補強する場 合, 既存躯体側には，チッピングによる目荒らし（以下，本論文で 扱う「目荒らし」は，特記のない限りチッピングによる目荒らしを 意味する）を施したあとに，接着系あと施工アンカーを配置し，補 強部材側には，割裂防止用のフープ筋を設置し，グラウトを圧入す ることで，既存躯体と補強部材が一体化される接合工法が多く採用 される。地震時において, せん断力を既存躯体から補強部材一確実 に伝達させるためには，上述した既存躯体と補強部材の一体性が非 常に重要である。チッピングによる目荒らしは, 凹凸面の噛み合い 効果によって, 接合面でのせん断抵抗を発揮する。しかしながら, 目荒らしの面積・深さ等によって定まる形状は，施工者の技術や設 計監理者・施工管理者の意識によって相違する。このため, 目荒ら し面の形状を厳密に管理することは極めて困難であると推察される。 また，各規・基準においても目荒らし面の凹凸形状は統一的に規定
されていない。

さらに加えると，現行の間接接合部の設計 1)において，せん断耐 力式は，あと施工アンカーに関する項目のみが用いられており，目 荒らしのせん断抵抗は考慮されていないため, 目荒らしは補助的に おこなうものと認識されやすい。

ここで，幾つかの既往の実験結果 2),3)を観察すると，目荒らしを 施さず，あと施工アンカーのみを施工した接合部実験の結果，設計 耐力を下回るが，目荒らしを施すことによって，設計耐力を上回る ことが報告されている。つまり，現状の設計法では条件によって危 険側になることがあると言えよう。そこで，より適切に合理的かつ 安全な接合部の設計を実現するためにも，実情に合わせ，目荒らし とあと施工アンカーの両者を組み合わせた設計法を構築する必要が あると考えられる。しかしながら, 既往の文献を調査しても, チッ ピングによる目荒らしのせん断抵抗性能を定量的に評価した研究は, ほとんど見当たらない。一方で，コンクリート構造に関する研究分 野では，コンクリートひび割れ面のせん断応力伝達機構を定量的に 評価できる，幾つかの力学モデル（構成則）が提案されている。具

\footnotetext{
*1 室蘭工業大学大学院工学研究科環境創生工学系専攻 大学院生 (現 日立建設設計)

*2 室蘭工業大学大学院工学研究科くらし環境系領域 准教授・博士 (工学)

*3 飛島建設耐震ソリューション部 主任

*4 飛島建設耐震ソリューション部 主任・修士(工学)

*5 東亜建設工業技術研究開発センター 主任研究員・博士 (工学)

*6 東洋大学理工学部建築学科 教授・博士 (工学)
}

Grad Student Div of Sustainable and Environmental Engineering Muroran Inst. of Technology (Present affiliation is Hitachi Architects \& Engineers Corporation) Assoc. Prof., College of Environmental Technology, Muroran Institute of Technology, Dr.Eng.

Chief, Seismic Solution Dept, TOBISHIMA Corporation

Chief, Seismic Solution Dept., TOBISHIMA Corporation, M.Eng. Senior Researcher, Research and Develop Center, TOA Corporation, Dr.Eng. Prof., Dept. of Architecture, Fac. of Sci. \& Eng., Toyo University, Dr.Eng. 
体的には, 実験結果をシミュレーションすることで構築された「実 験経験ひび割れモデル」4),5)，コンクリート内の骨材の最大寸法や粒 度分布などから, ひび割れ面の形状をモデル化し, 構成則に組み込 んだ「仮想ひび割れモデル」6),7), 実ひび割れ面の形状測定実験から 得られた 3 次元座標データを用いて算出した形状特性を構成則に組 み込んだ「物理接触モデル」8),99の 3 種類に大別される。

この中で, 様々な形状を呈する目荒らし面のせん断応力伝達機構 を扱う上では, 形状測定結果を用いる物理接触モデルが最も適合し 易いように考えられる。既往の文献 8),9 によよれば，微小凹凸面に作 用する接触応力を界面全体の面積で積分することにより，ひび割れ 面全体に作用するせん断応力と垂直応力を再現できる。つまり，こ の理論を応用することで, 目荒らし面のせん断応力伝達機構を定量 的に評価できる可能性が高い。そこで, 本論文では, はじめに目荒 らし面の形状特性を把握するために, 高感度スポットレーザー変位 計（以下，レーザー変位計と呼称する）を用いた形状測定, および 形状分析を行い，次いでせん断抵抗性能を評価するために目荒らし のみを施した試験体のせん断載荷実験を行う。最後に, 目荒らし面 のせん断抵抗性能の定量評価に寄与寸心゙く, 目荒らし面の力学挙動 を再現するための力学モデルを構築する。

\section{2. コンクリート目荒らし面におけるせん断応力伝達機構を解明す るための実験概要}

既述したように，一般的な耐震補強の接合面では，あと施工アン カーと目荒らしが併用されており, 力学的に両者が互いに影響を及 ぼし合うものと考えられる。しかし，本論文では，まずは目荒らし のせん断応力伝達を定量評価するため, 目荒らしのみに焦点を当て, 目荒らしのみを施した試験体のせん断載荷実験を行う。

\section{1 試験体の諸元と実験パラメータ}

Fig. 1 に試験体の諸元寸法を, Table 1 に実験パラメータを示す。 既存躯体側コンクリートは $580 \mathrm{~mm} \times 400 \mathrm{~mm} \times 200 \mathrm{~mm}$, 補強部材側 グラウトは $375 \mathrm{~mm} \times 200 \mathrm{~mm} \times 200 \mathrm{~mm}$ の直方形状である。このコン クリート断面は既存梁を模擬して幅 $400 \mathrm{~mm}$ とし, 同様にグラウト 断面は, 耐震補強の接合部を模擬し $200 \mathrm{~mm} \times 200 \mathrm{~mm}$ としている。 次節でも触れるが，形状測定およびせん断載荷実験では同一の試験 体を用いる。既存躯体側コンクリートの試験領域は， $375 \mathrm{~mm}$ $\times 200 \mathrm{~mm}$ とし，これを接合面と呼称する。

実験パラメータは目荒らし面積比 $r_{c r}$ (接合面面積 $A_{j}$ に対する目 荒らし部の水平投影面積 $A_{c r}$ の比）および目荒らし深さである。想 定する $r_{c r}$ は $0.1 ， 0.2 ， 0.3 ， 0.5 ， 0.75$ の 5 段階とする。 $r_{c r}$ が 0.1 , $0.2,0.3$ の試験体は, 目荒らし深さが標準および深めとしたものを 1 体ずつ用意し, 形状特性を比較する。試験体名は, $\mathrm{CH}$ 記号の後 ろに, 面積比を意味する数值と深さを表す記号（Nまたは D）を併 記して構成される。なお, Table 1 に各試験体の最大目荒らし深さ も併記している。

Table 2 にコンクリートとグラウトの材料特性を示す。既存躯体 側コンクリートおよび補強部材側グラウトの圧縮強度 $\sigma_{B}$ の組合せ は, 載荷時期の違いから, それぞれ $17.1 \mathrm{~N} / \mathrm{mm}^{2}$ および $64.6 \mathrm{~N} / \mathrm{mm}^{2}$, または $19.9 \mathrm{~N} / \mathrm{mm}^{2}$ および $68.7 \mathrm{~N} / \mathrm{mm}^{2}$ である。

\section{2 試験体製作方法}

既存部コンクリート側の型枠を垂直に設置した後, 型枠内に鉄筋
を配筋し,コンクリートを打設する。接合面となる試験体上面には, 表面加工コンクリート型枠用合板を用いており，接合面は平滑な仕 上がりとなっている。その後, 接合面に打撃型の電動工具（以下， ハンマードリルと呼称する）を用いて，目荒らしを施す。目荒らし を施工する際の $r_{c r}$ の確認方法として, 画像解析を用いる。まず，平 滑な接合面に黒色の塗料を塗装し，その後目荒らしを施工する。目 荒らしを施すと黒色の塗料がついたコンクリートが除去されるため, 接合面をコンクリートと黒色の塗料の 2 色で表すことができる。こ れらの色相の違いを利用して画像解析を行い， $r_{c r}$ を確認していく。 Photo 1 に本試験体の目荒らし面の施工状況を示す。Table 1 に画像 解析結果による $r_{c r}$ の実測值も併記している。想定目荒らし面積比と 比較すると，概ね意図したとおりの面積比で，目荒らしを施工でき ていることが分かる。 $r_{c r}$ の確認後，目荒らし面の形状測定を行う。 目荒らし面の 3 次元座標データを取得したのち， $375 \mathrm{~mm} \times 200 \mathrm{~mm}$ $\times 200 \mathrm{~mm}$ の間接接合部の型枠を接合面の上に設置する。最後に鉄 筋籠を配置し，型枠内にグラウトを打設する。鉄筋籠は，結束線を

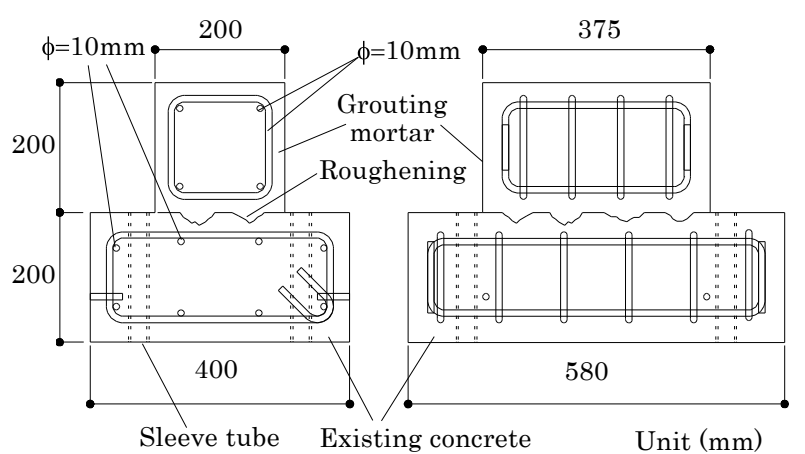

Fig. 1 Dimension specification of specimen

\begin{tabular}{|c|c|c|c|c|}
\hline Specimen & $r_{c r}$ & $\begin{array}{c}\text { Measured } \\
r_{c r}\end{array}$ & $\begin{array}{l}\text { Depth } \\
\text { type }\end{array}$ & $\begin{array}{c}\text { Maximum } \\
\text { depth }\end{array}$ \\
\hline $\mathrm{CH}-10 \mathrm{~N}$ & \multirow{2}{*}{0.100} & 0.099 & Normal & $17.1 \mathrm{~mm}$ \\
\hline $\mathrm{CH}-10 \mathrm{D}$ & & 0.117 & Deep & $23.9 \mathrm{~mm}$ \\
\hline $\mathrm{CH}-20 \mathrm{~N}$ & \multirow{2}{*}{0.200} & 0.213 & Normal & $10.7 \mathrm{~mm}$ \\
\hline $\mathrm{CH}-20 \mathrm{D}$ & & 0.182 & Deep & $20.7 \mathrm{~mm}$ \\
\hline $\mathrm{CH}-30 \mathrm{~N}$ & \multirow{2}{*}{0.300} & 0.290 & Normal & $14.7 \mathrm{~mm}$ \\
\hline $\mathrm{CH}-30 \mathrm{D}$ & & 0.308 & Deep & $20.5 \mathrm{~mm}$ \\
\hline $\mathrm{CH}-50 \mathrm{~N}$ & 0.500 & 0.499 & Normal & $18.3 \mathrm{~mm}$ \\
\hline $\mathrm{CH}-75 \mathrm{~N}$ & 0.750 & 0.777 & Normal & $18.5 \mathrm{~mm}$ \\
\hline
\end{tabular}

$r_{c r}$ : Area ratio of roughening

Table 2 Material properties of concrete and grouting mortar

\begin{tabular}{ccccc}
\hline \multirow{2}{*}{$\begin{array}{c}\text { Specimen } \\
\text { Material }\end{array}$} & $\begin{array}{c}\text { Compressive } \\
\text { strength } \\
\left(\mathrm{N} / \mathrm{mm}^{2}\right)\end{array}$ & $\begin{array}{c}\text { Young's } \\
\text { modulus } \\
\left(\mathrm{kN} / \mathrm{mm}^{2}\right)\end{array}$ & $\begin{array}{c}\text { Splitting } \\
\text { strength } \\
\left(\mathrm{N} / \mathrm{mm}^{2}\right)\end{array}$ \\
\hline \hline $\mathrm{CH}-10 \mathrm{~N}, \mathrm{CH}-30 \mathrm{~N}$ & Concrete & 17.1 & 24.7 & 1.83 \\
\cline { 2 - 6 } $\mathrm{CH}-50 \mathrm{~N}, \mathrm{CH}-75 \mathrm{~N}$ & Grouting mortar & 64.6 & 26.2 & 2.10 \\
\hline $\mathrm{CH}-10 \mathrm{D}, \mathrm{CH}-20 \mathrm{D}$ & Concrete & 19.9 & 29.1 & 1.90 \\
\cline { 2 - 6 } $\mathrm{CH}-20 \mathrm{~N}, \mathrm{CH}-30 \mathrm{D}$ & Grouting mortar & 68.7 & 26.3 & 3.42 \\
\hline
\end{tabular}




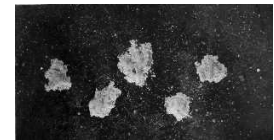

(a) $\mathrm{CH}-10 \mathrm{~N}$

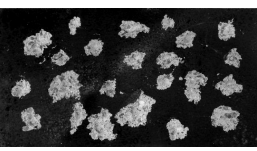

(c) $\mathrm{CH}-20 \mathrm{~N}$

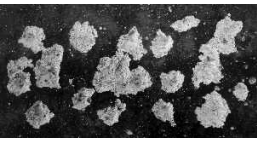

(e) $\mathrm{CH}-30 \mathrm{~N}$

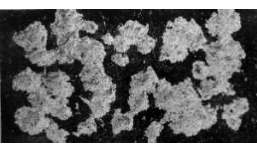

(g) $\mathrm{CH}-50 \mathrm{~N}$

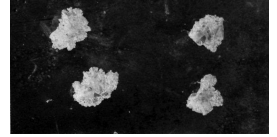

(b) $\mathrm{CH}-10 \mathrm{D}$

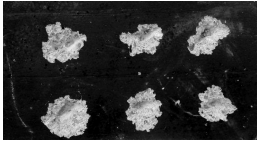

(d) $\mathrm{CH}-20 \mathrm{D}$

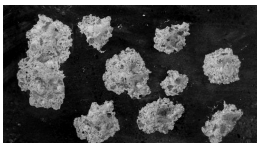

(f) $\mathrm{CH}-30 \mathrm{D}$

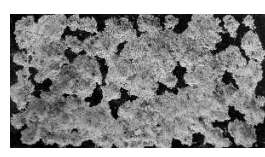

(h) $\mathrm{CH}-75 \mathrm{~N}$
Photo 1 Roughened concrete surface
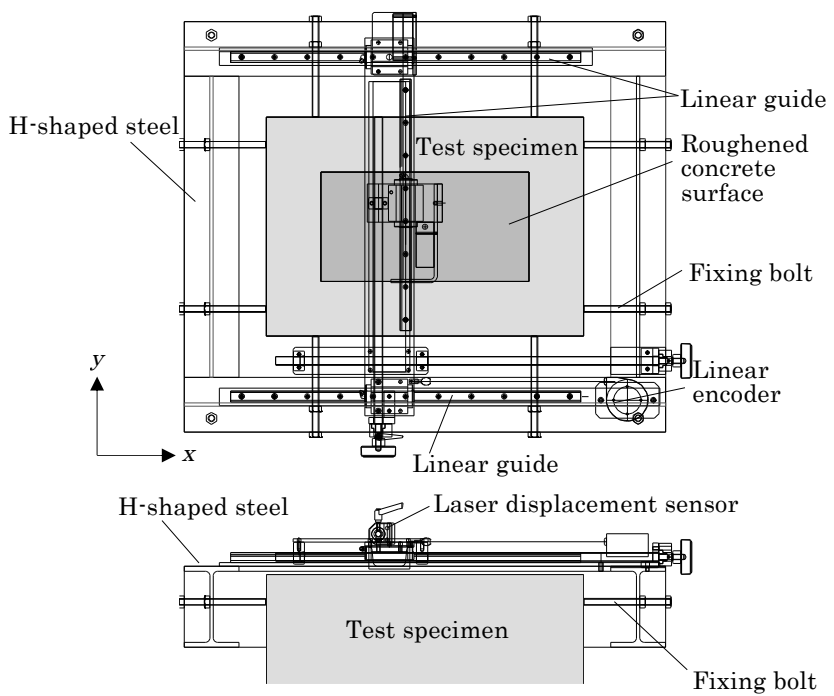

Fig. 2 Measurement equipment of shape

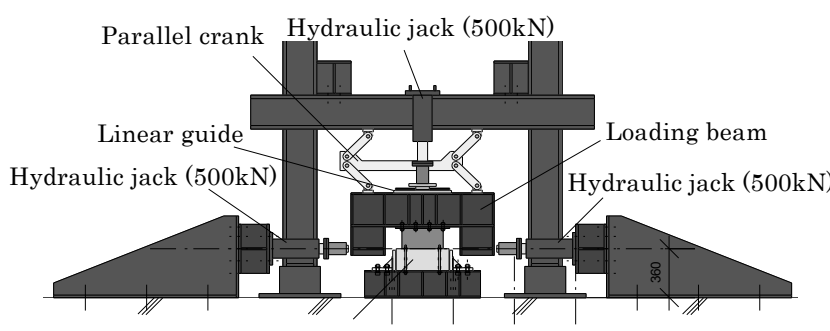

Fig. 3 Loading equipment

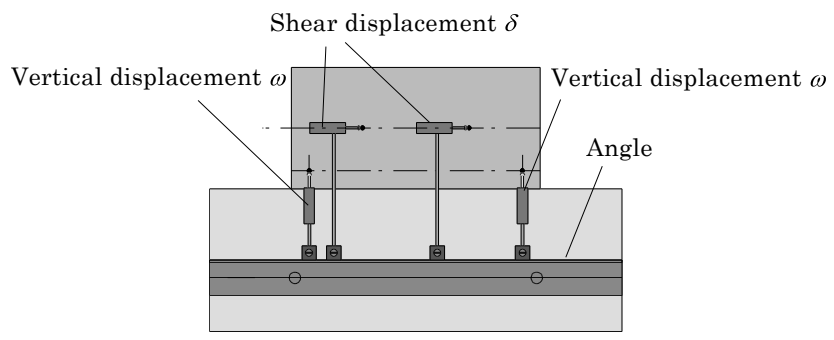

Fig. 4 Measurement method of shear loading test

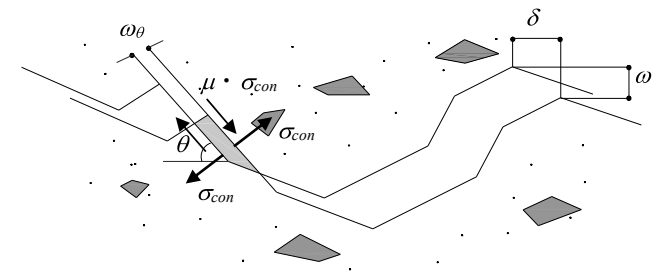

Fig. 5 Image of contact on local surface

用いて型枠から吊るすことで固定されており，接合面にスペーサー 等の異物が混在しないように配慮している。グラウトはプレミック スタイプを使用し, 添加する水量は材料指定の範囲内とする。なお, 目荒らしを施さない平滑な接合面には，グリスを塗布し，既存躯体 側コンクリートと補強部材側グラウト間に生じる, 付着抵抗や摩擦 抵抗の影響が極力小さくなるように配慮する。

\section{3 目荒らしの形状測定実験}

Fig. 2 に形状測定装置図を示す。Fig. 2 に示すように，レーザー 変位計およびリニアエンコーダーを用いた，形状測定装置を構築す る。形状測定を行う試験体の周囲に，リニアガイドを取り付けた $\mathrm{H}$ 形鋼をボルトで固定する。リニアガイドに設置されたレーザー変位 計を $x, y$ 方向に走査させながら,$z$ 方向の深さを計測することで, 目荒らし面の 3 次元座標データを取得していく。測定間隔は $x$ 方向 (せん断方向), $y$ 方向で，それぞれ $0.04 \mathrm{~mm}, 0.5 \mathrm{~mm}$ とする。

\section{4 せん断載荷実験の加力および計測方法}

Fig. 3 に加力装置図を示す。同図に示すように加力装置は, 軸力 の制御と正負交番繰り返しの水平加力を制御するために, 最大荷重 $500 \mathrm{kN}$ の油圧ジャッキをそれぞれ使用する。軸方向は一定荷重とす る。なお, この一定軸力について, 接合部の変位場や応力場を詳細 に解明した研究はほとんど行われていないが，この数少ない報告例 の中でも，文献 10)において，内付け補強の接合部に生じる軸方向 応力度 $\sigma$ が $0.4 \mathrm{~N} / \mathrm{mm}^{2}$ 程度であると報告されている。このため本実 験では, 本研究と関連する一連の実験 11 去どでの条件と合わせ $\sigma=$ $0.48 \mathrm{~N} / \mathrm{mm}^{2}$ 一定となるように軸力を与えることとした。水平方向は, 相対水平変位 $\delta$ を变位制御しながら, 正負交番の繰り返し載荷を行 う。載荷サイクルは $\delta= \pm 0.12 \mathrm{~mm}$ を 1 サイクル $\delta= \pm 0.25 \mathrm{~mm}$, $\pm 0.5 \mathrm{~mm}, \pm 1.0 \mathrm{~mm}, \pm 2.0 \mathrm{~mm}, \pm 4.0 \mathrm{~mm}$ を 2 サイクル $\delta=+6.0 \mathrm{~mm}$ を 1 サイクルとする。繰り返しの水平加力位置を, 試験体の接合面と 同じ高さにすることで, 加力による偏心を極力小さくした。軸力は, 加力ビームを水平に保持しつつ, 油圧ジャッキを使用し，所定の荷 重となるように制御した。

Fig. 4 に計測方法を示す。同図に示すように，既存躯体側コンク リートに固定した鋼製アングルの上に変位計を設置し，そこから補 強部材側グラウトに取り付けたターゲットに対する，離間距離（以 下，目開き量 $\omega$ と呼ぶ）と相対水平変位 $\delta$ をそれぞれ計測する。

\section{3. コンクリート目荒らし面のせん断応力伝達機構のモデル化}

1 章でも述べた通り, 本研究では, 凹凸形状とせん断応力伝達の 関係が明快な物理接触モデル 8),9)を採用する。本論文では，微小凹 凸面の摩擦を考慮した Bujadaham のモデル 9)をベースに, 目荒ら し面のせん断応力伝達機構を記述することとする。 


\section{1 微小凹凸面に作用する接触応力}

Fig. 5 は，摩擦を考慮した場合の微小凹凸面に作用する接触応力 を概念的に表したものである。接触応力に基づく力学モデル 8),9)で は, 微小凹凸面に作用する接触直応力 $\sigma_{c o n}$ と摩擦応力 $\left(\mu \times \sigma_{c o n}\right)$ を せん断成分と垂直成分に分解して, 傾斜密度関数 $\Omega(\theta)$ および接触面 有効率 $K$ を乗じ, 界面全体にわたって積分することによって, ひび 割れ面のせん断応力と垂直応力がそれぞれ算出される。これらを数 式化すると，Fig. 5 の概念図より以下の式が導かれる。

$$
\begin{aligned}
& \tau=\int_{-\pi / 2}^{\pi / 2} K \cdot \sigma_{c o n} \cdot \Omega(\theta) \cdot(\sin \theta+\mu \cos \theta) d \theta \\
& \sigma=\int_{-\pi / 2}^{\pi / 2} K \cdot \sigma_{c o n} \cdot \Omega(\theta) \cdot(\cos \theta-\mu \sin \theta) d \theta
\end{aligned}
$$

ここに, $\theta$ は微小面の傾斜角, $\mu$ は摩擦係数である。ここで, 現 場打ち同等型プレキャスト鉄筋コンクリート構造設計指針 (案) ・同 解説 ${ }^{12)}$ において摩擦係数は, 打ち継ぎ面に表面処理を行わない場合 は $\mu=0.6$, 人為的凹凸面を設けた場合は $\mu=1.0$ を用いることになっ ている。本論文では Fig. 5 に示すように, 微小凹凸面に作用する摩 擦を扱うことから，フラットな面同士が接触した際の摩擦として捉 えることができるため， $\mu=0.6$ を採用する。

さらに, 既往の理論 8),9)に従えば, 目開き量が大きくなるほじ, 微小凹凸面の接触面積が減少し, 伝達される応力が低下寸る。これ を表す低減係数が $K$ として表現されている 8)。本論文では, Table 1 で示した, 目荒らし面の最大深さ $D_{\max }$ を用いて, 次式で $K$ を表す。

$$
K=1-2 \omega / D_{\max }
$$

ここで, 純粋に既往の式 8)を用いると, 目開きによる応力低下を 十分に表せなかったため, この式(3)による低下率 $\left(2 \omega / D_{\max }\right)$ は既往 のモデルの 2 倍の值に相当する式を用いている。この凹凸面の深さ 成分の影響については, 今後の課題としたい。

\section{2 傾斜密度関数 $\Omega(\theta)$}

コンクリートひび割れ面を対象とした既往のモデル 8),9)では，傾 斜密度関数として $\Omega(\theta)=0.5 \cos \theta$ が採用されているが，本研究では 目荒らし面を対象としているため, 本提案モデルに適用できる可能 性は低い。特に本実験では， $r_{c r}$ を違えた試験体を使用しており, 試 験体毎に傾斜密度分布が異なると考えられる。また, 前述した通り, 目荒らしは施工者の技能や意識によって形状が異なるランダム特性 を有しているため, 同じ $r_{c r}$ でも違いが見られる可能性がある。そこ で本論文では, 目荒らし面の形状測定実験から得られた 3 次元座標 データを用いて, 各試験体の傾斜密度分布を算出する。Fig. 6 に形 状分析方法を示す。目荒らし面の形状測定実験の際, 試験体の設置 精度によって，接合面が僅かに傾いた状態で計測されている可能性 がある。そのため, はじめに, 取得した目荒らし面の 3 次元座標デ 一タを補正する。Fig. 6 に示しているように，目荒らしを施してい ない平滑な面を対象とし, 最小二乗法を用い, 座標基準面を算出す る。その後, 求めた座標基準面の傾きによって, 測定した 3 次元デ 一夕を座標変換し，傾斜角 $\theta$ に関する形状分析を行う。

微小面の傾斜角 $\theta$ は隣接する $i+1$ 点の座標值 $\left(x_{i+1,} Z_{i+1}\right)$ を用いて下 式で表すことができる。

$$
\theta_{i}=\tan ^{-1}\left\{\left(z_{i+1}-z_{i}\right) /\left(x_{i+1}-x_{i}\right)\right\}
$$

傾斜角 $\theta$ の頻度分布を接合面面積 $A_{j}$ で積分し, さらに式(5)の積分
值が 1 になるように調整して得られる值が傾斜密度分布である。

$$
\int_{-\pi / 2}^{\pi / 2} \Omega(\theta) d \theta=1
$$

$r_{c r}$ がそれぞれ 0.1 0.75 の試験体の傾斜密度分布を Fig. 7 に示す。 同図の棒グラフは，深さが異なる試験体の平均值である。いずれの 試験体も $\theta=0(\mathrm{rad}$.$) でピークを示し， \theta= \pm \pi / 2(\mathrm{rad}$.$) 近傍になるにつ$ れ， $\Omega(\theta)$ が徐々に小さくなる傾向がみられる。また $r_{c r}$ が大きくな るにつれ，ピーク時の $\Omega(\theta)$ は小くなり，かつ $\theta= \pm \pi / 2$ 近傍では $\Omega(\theta)$ が大きくなっている。ただし， $r_{c r}=0.2$ と 0.3 を比較すると， $r_{c r}=0.2$ の方が $\theta= \pm \pi / 2(\mathrm{rad}$.$) 近傍の \Omega(\theta)$ が僅かに大きくなっている。

また $r_{c r}=0.1 \sim 0.3$ では，深さが異なる 2 種類の試験体を用意し， 傾斜角に関する形状分析を行った結果，傾斜密度分布に特段の差異 はみられなかった。

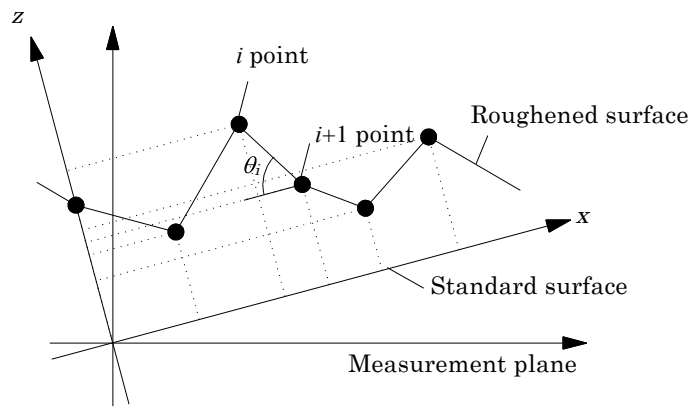

Fig. 6 Shape analysis method
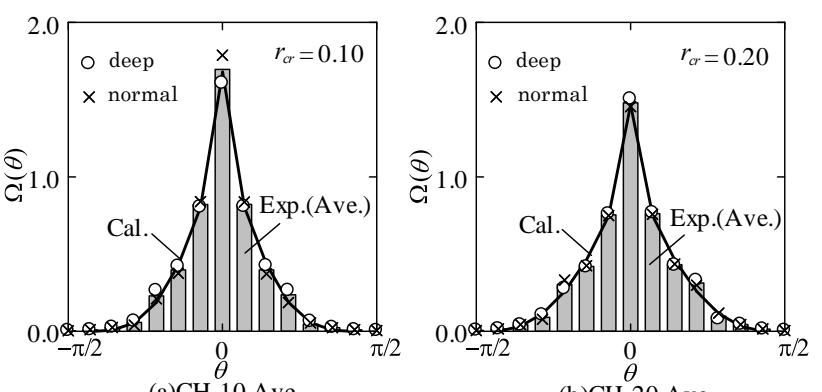

(a) $\mathrm{CH}-10$ Ave.

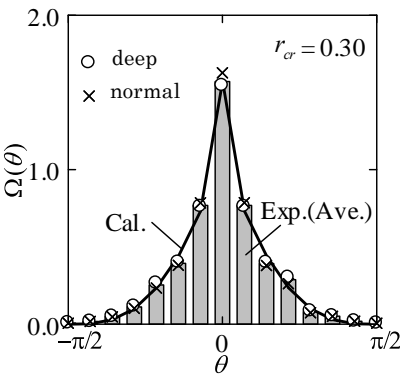

(c) $\mathrm{CH}-30$ Ave.

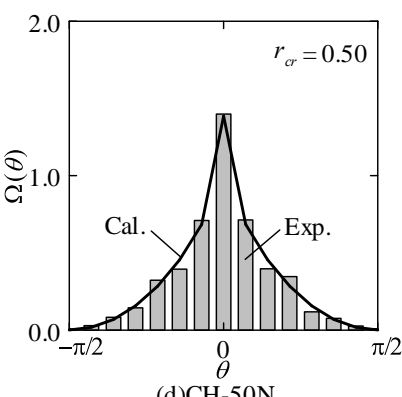

(d) $\mathrm{CH}-50 \mathrm{~N}$

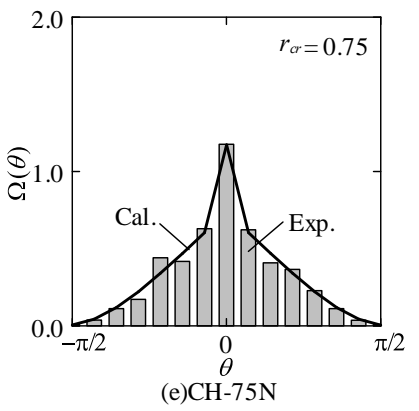

Fig. 7 Inclined density distribution 
Table 3 Parameter of angle density function

\begin{tabular}{|c|c|c|c|c|}
\hline \multirow{2}{*}{ Specimen } & \multicolumn{4}{|c|}{ Parameter } \\
\cline { 2 - 5 } & $a_{0}$ & $a_{1}$ & $n$ & $m$ \\
\hline CH-10 Ave. & 1.26 & -1.18 & 0.42 & 3.40 \\
\hline CH-20 Ave. & 1.10 & -1.00 & 0.42 & 1.70 \\
\hline CH-30 Ave. & 1.18 & -1.06 & 0.36 & 2.25 \\
\hline CH-50N & 1.04 & -0.90 & 0.36 & 1.25 \\
\hline CH-75N & 0.88 & -0.54 & 0.18 & 1.90 \\
\hline
\end{tabular}

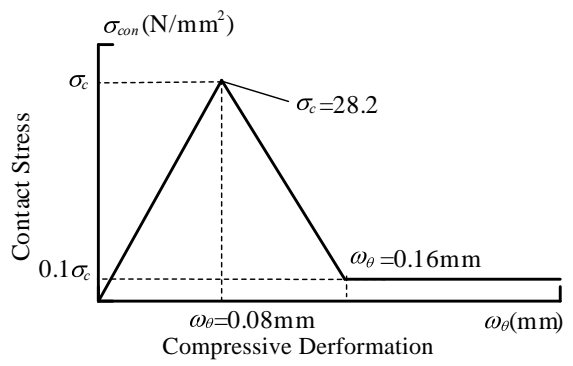

Fig. 8 Contact stress on local roughness

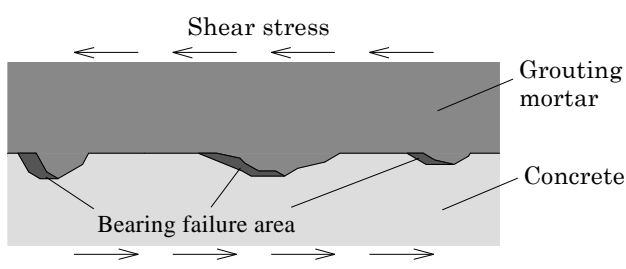

(a) $r_{c r}=0.1 \sim 0.3$

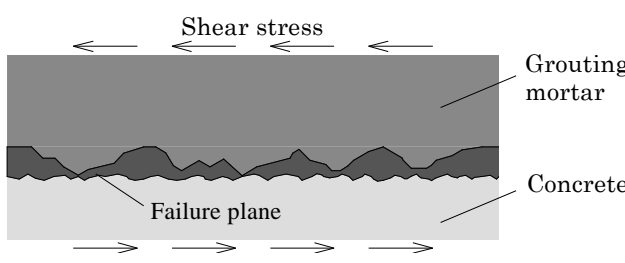

(b) $r_{c r}=0.5,0.75$

Fig. 9 Failure mode

既述したように, 目荒らし面に関する形状や載荷実験の結果には, 粗面特有のバラツキを内包しているが，本論文で用いている物理接 触モデルは, 非常に緻密で解析パラメータに敏感な特性を持つ。こ のランダム性に富む現象を物理接触モデルに適用して実験結果を再 現するには，個々の試験体のバラッキを平滑化して使用した方が, 解析結果が安定すると考えられる。さらに, 後述するせん断載荷実 験結果より, 同じ $r_{c r}$ の試験体では, 最大応力および変形性能にも 大きな違いがなかった。そこで本論文で提案するモデルでは, 傾斜 角のみを扱うこととし, さらに傾斜密度分布の深さによる影響が小 さいことからも, Fig. 7 の通り $\Omega(\theta)$ には $r_{c r}$ 毎の平均值を扱う。

\section{3 傾斜密度関数 $\Omega(\theta)$ のシミュレーション}

前掲の Fig. 7 には $r_{c r}$ 毎の $\Omega(\theta)$ および提案する傾斜密度関数のシ ミュレーション式の值を併記している。形状測定実験による 3 次元 座標データを分析して得られた傾斜密度分布を本力学モデルに組み 込むには，これらを数式化する必要がある。ここでは，傾斜密度分 布のシミュレーション式として次式を用いることとする。

$$
\Omega(\theta)=\frac{4}{3}\left(a_{0}+a_{1} \cdot|\theta|^{n}\right) \cdot \cos ^{m} \theta
$$

ここに, 式(6)の $a_{0}, a_{1}, n, m$ は係数で, Table 3 に目荒らし面積比 に応じて傾斜密度関数を表す各係数の值を示す。これらの係数は試 験体毎の傾斜密度分布に対して, 最小二乗法を用いて算出している。

Fig. 7 に, 本シミュレーション式と計測結果の比較を示す。本シ ミュレーション式によって, 各試験体の傾斜密度分布を概ね良好に 再現できていることがわかる。

\section{4 接触直応カのモデル化}

目荒らし面の応力伝達機構に適応させるための接触直応力のモデ ルを構築する。Fig. 8 に微小凹凸面の接触直応力をモデル化したも のを示す。接触変位 $\omega_{\theta}$ は微小凹凸面の接触直応力の接触変位であり, 下式で表される ${ }^{8)}$

$\omega_{\theta}=\delta \sin \theta-\omega \cos \theta$

ここで，既往のモデル 8),9) と同様に，ピークまでは線形でモデル 化する。ポストピーク領域の目荒らし面のせん断応力伝達は, 微小 凹凸面の支圧破壊で決まると考えられるため，圧縮特性の応力軟化 を考慮することとし，Darwin-Pecknold ${ }^{13)}$ による一軸圧縮軟化特性 の関係を参考に接触応力のモデル化を行う。この特性 ${ }^{13)}$ は，コンク リートの圧縮強度 $\sigma_{B}$ 以降, 直線的に応力が軟化し, $\sigma_{B}$ 時の圧縮ひず み $\varepsilon_{B}$ の 4 倍の圧縮ひずみ $4 \varepsilon_{B}$ のとき, 圧縮応力度が $0.2 \sigma_{B}$ の点を通 る。このモデルを目荒らし面の接触モデルとして用いるため, 圧縮 ひずみを接触変位 $\omega_{\theta}$, 圧縮応力度 $\sigma$ を接触応力 $\sigma_{c o n}$ と置き換え, モ デルを構築する。純粋な一軸圧縮状態に比べ，目荒らし面の微小凹 凸面の接触面では，脆性的な破壊が生じると考えられること，およ び次章で述べる実験結果と整合させることを目的に，Darwin -Pecknold モデルを一部修正する。つまり, 最大接触応力 $\sigma_{C}$ の 2 倍 の接触変位のとき, 接触応力が $0.1 \sigma_{C}$ の点を通るようにする。また, 一般に，局所的に作用寸る支圧強度は，一軸圧縮強度よりも大きく なる。そこで本論文では, 最小二乗法を用いて実験結果の $\tau-\delta$ 曲線に フィットするよう $\sigma_{C}=28.2 \mathrm{~N} / \mathrm{mm}^{2}$, および $\omega_{\theta}=0.08 \mathrm{~mm}$ と定める。 なお本実験では，Table 2 に示す通り，2 種類の $\sigma_{B}$ があるが，両者 に大きな差はないため, 同等に扱って $\sigma_{C}$ を算出している。

\section{4. 実験結果と本提案モデルの適合性}

本章では，本提案モデルとせん断載荷実験の結果を比較し，その 適合性について検証する。なお，本実験では，正負交番繰り返し載 荷を行っているが，研究の初期段階として，正側の包絡曲線に主眼 をおくこととする。

\section{1 目荒らしした試験体の破壊形式}

Fig. 9 に試験体の破壊形式と概念図を示す。せん断載荷実験後の 試験体を観察すると， $r_{c r}$ が 0.1 0.3の試験体では目荒らし面の凹凸 部分で支圧を受け，既存躯体側コンクリートの支圧破壊が支配的で ある。 $r_{c r}$ が 0.5 および 0.75 の試験体では, 支圧破壊はほとんど認 められず，既存躯体側コンクリートと補強部材側グラウトが一体と なって，ある深さの位置でせん断破壊（以下，シアオフ破壊例えば 14) と呼称する）した。これらの事実から，本実験の範囲では， $r_{c r}$ が 0.5 を超えると，既存躯体側と補強部材側が一体となって破壊する と判断される。しかしながら，コンクリートの圧縮強度や軸応力な じ，より詳細な検証が必要である。 


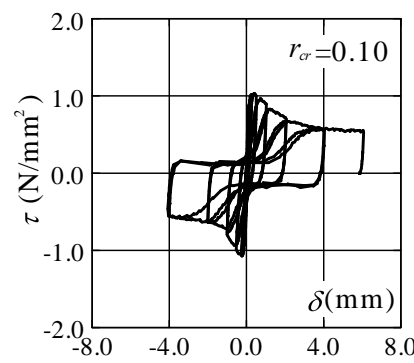

(a) $\mathrm{CH}-10 \mathrm{~N}$

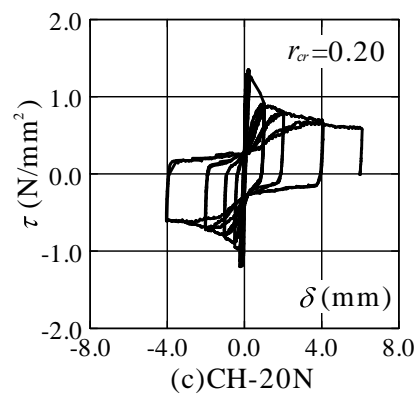

(c) $\mathrm{CH}-20 \mathrm{~N}$
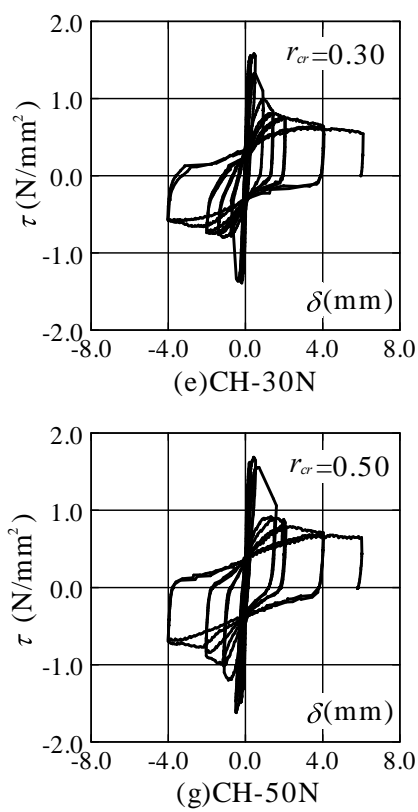

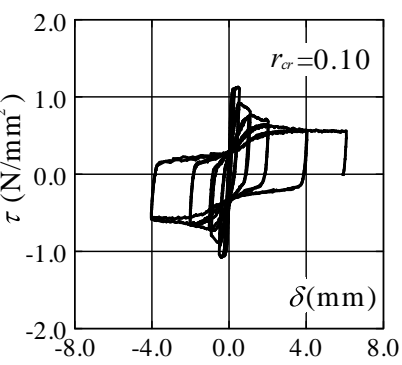

(b) $\mathrm{CH}-10 \mathrm{D}$

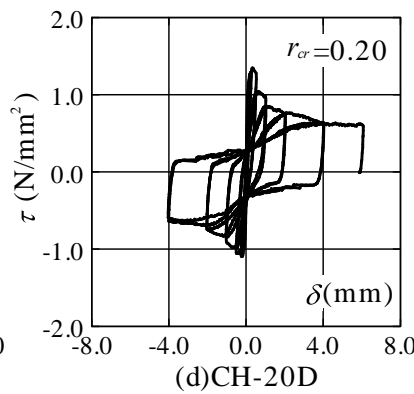

(d) $\mathrm{CH}-20 \mathrm{D}$

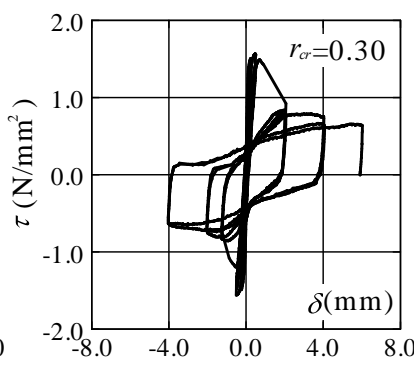

(f) $\mathrm{CH}-30 \mathrm{D}$

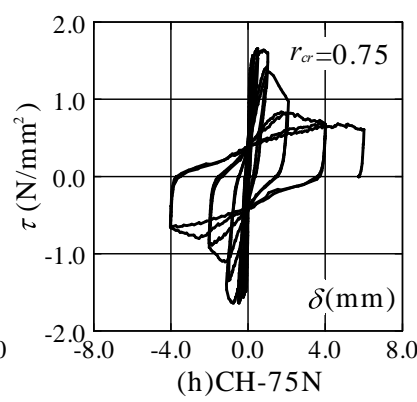

(h) $\mathrm{CH}-75 \mathrm{~N}$
Fig. 10 Shear stress - slip curves

\section{2 せん断載荷実験結果}

Fig. 10 にせん断応力 $\tau$ 一せん断変位 $\delta$ 曲線 を, Table 4 に最大応 力 $\tau_{\max }$ とその時の $\delta$, および正負の比を示す。試験体毎に正負それぞ れの最大応力点を比較すると, 正負で概数対称な曲線形状を示して いる。

次に， $r_{c r}$ が異なる試験体で比較する。いずれの試験体の $\tau-\delta$ 曲線 は, 最大応力まではやや非線形挙動を呈しているが, 本研究で評価 対象としている $\delta=6 \mathrm{~mm}$ の範囲付1)では, 提案モデルと同様にほぼ線 形挙動とみな寸ことができる。ピーク後, 応力が急激に低下し, あ る程度応力が低下寸ると応力一定で推移する。また, Fig. 10 および Table 4 より， $r_{c r}$ が大きくなるにつれ最大応力も大きくなる。しか し, $r_{c r}$ が 0.3 を超えると, 最大応力の差異が小さくなる。これは 上述した， $r_{c r}$ が 0.3 を超えると破壊形式が支圧破壊からシアオフ 破壊一移行することに依拠するためと推量され, 最大応力に $r_{c r}$ が
Table 4 Experimental results of maximum strength

\begin{tabular}{|l|c|c|c|c|c|}
\hline Specimen & $\begin{array}{c}\text { Shear } \\
\text { displacement } \\
+\delta \\
(\mathrm{mm})\end{array}$ & $\begin{array}{c}\text { Maximum } \\
\text { Strength } \\
+\tau_{\max } \\
\left(\mathrm{N} / \mathrm{mm}^{2}\right)\end{array}$ & $\begin{array}{c}\text { Shear } \\
\text { displacement } \\
-\delta \\
(\mathrm{mm})\end{array}$ & $\begin{array}{c}\text { Maximum } \\
\text { Strength } \\
-\tau_{\max } \\
\left(\mathrm{N} / \mathrm{mm}^{2}\right)\end{array}$ & $\begin{array}{c}-\tau_{\max } \\
+\tau_{\max }\end{array}$ \\
\hline $\mathrm{CH}-10 \mathrm{~N}$ & +0.39 & +1.04 & -0.24 & -1.07 & 1.03 \\
\hline $\mathrm{CH}-10 \mathrm{D}$ & +0.46 & +1.13 & -0.41 & -1.08 & 0.95 \\
\hline $\mathrm{CH}-20 \mathrm{~N}$ & +0.20 & +1.36 & -0.22 & -1.20 & 0.88 \\
\hline $\mathrm{CH}-20 \mathrm{D}$ & +0.32 & +1.35 & -0.21 & -1.09 & 0.80 \\
\hline $\mathrm{CH}-30 \mathrm{~N}$ & +0.43 & +1.58 & -0.20 & -1.39 & 0.88 \\
\hline $\mathrm{CH}-30 \mathrm{D}$ & +0.47 & +1.57 & -0.50 & -1.56 & 0.99 \\
\hline $\mathrm{CH}-50 \mathrm{~N}$ & +0.43 & +1.69 & -0.48 & -1.62 & 0.96 \\
\hline $\mathrm{CH}-75 \mathrm{~N}$ & +0.47 & +1.66 & -0.47 & -1.64 & 0.99 \\
\hline
\end{tabular}

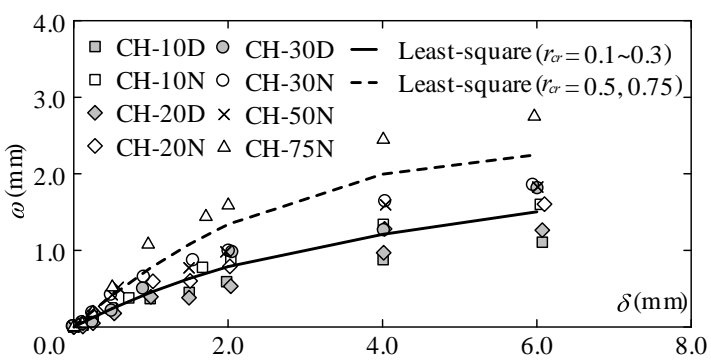

Fig. $11 \omega-\delta$ curves

依存していないことと整合する。ピーク後の破壞挙動では， $r_{c r}$ が 大きいほじ，応力低下が顕著である。次に同じ目荒らし面積比 $\left(r_{c r}\right.$ $=0.1,0.2,0.3)$ 毎に比較すると, 目荒らし深さの違いによる $\tau-\delta$ 関 係の違いは見られない。したがって本実験の範囲では，目荒らし深 さは $\tau-\delta$ 関係にほとんど影響ないことが分かる。

\section{3 実験結果と本提案モデルの比較}

せん断載荷実験結果と本提案モデルを比較し，再現精度を検証す る。Fig. 11 に目開き量 $\omega$ 一せん断変位 $\delta$ 曲線を，Fig. 12 にはせん 断載荷実験結果と本提案モデルの結果を示している。本論文では, 提案モデルを用いて, 全試験体を対象に解析を行うが, 当然ながら, 物理接触型の理論を適用した本モデルは，支圧破壊した試験体のみ に適用し得るものである。この観点から Fig. 11 を観察すると，同 じ破壊形式でも，ピーク応力となる，およそ $0.2 \sim 0.5 \mathrm{~mm}$ までは, $r_{c r}$ により $\omega$ に大きな違いはない。しかし，ピーク後は， $r_{c r}$ の大きさ に関わらず $\omega$ がばらついて推移している。また，傾斜密度分布と同 様に, 個々の試験体のバラツキを平滑化してモデルに組み込む方が， 安定した解析結果が得られると推察される。

そこで，まずは支圧破壊した $r_{c r}=0.1 \sim 0.3$ の試験体を対象に $\omega-\delta$ 関係を平均化する。次に参考として，シアオフ破壊した $r_{c r}=0.5$, 0.75 の試験体の $\omega-\delta$ 関係を平均化する。平均化手法としては, 最小 二乗法を用い, 式(8)および式(9)の近似曲線がそれぞれ得られる。

$$
\begin{aligned}
& \omega=0.005 \delta^{3}-0.076 \delta^{2}+0.527 \delta \\
& \omega=0.006 \delta^{3}-0.122 \delta^{2}+0.891 \delta
\end{aligned}
$$

なお, 実験值の $\tau$ および $\sigma$ はせん断荷重 $Q$, 軸力 $N$ を $A_{j}$ で除した 值を用いる。 


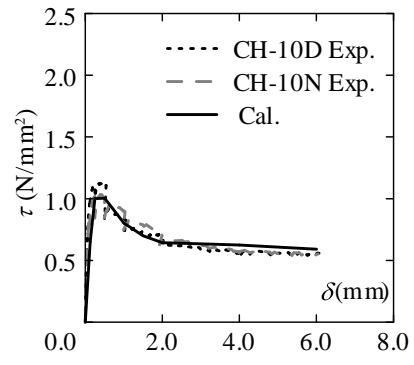

(a)CH-10 Ave.

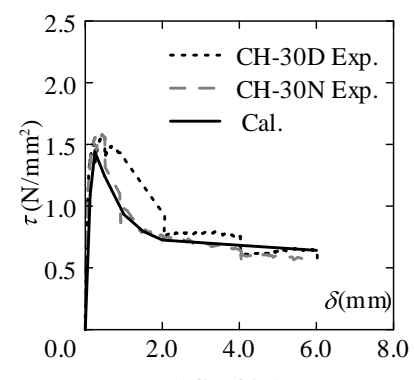

(c) $\mathrm{CH}-30$ Ave.

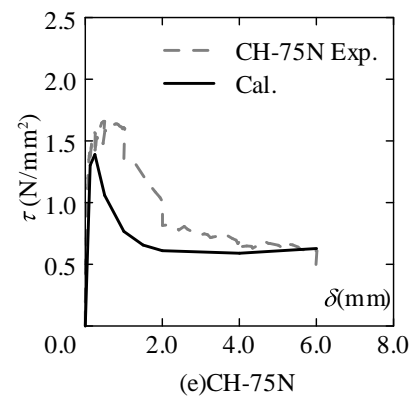

(e) $\mathrm{CH}-75 \mathrm{~N}$

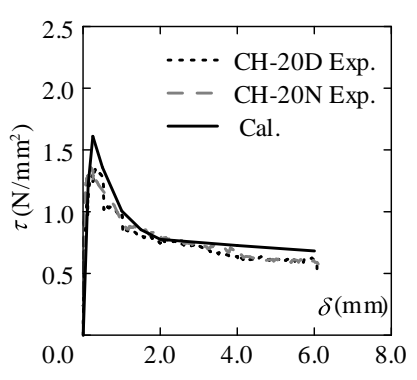

(b) $\mathrm{CH}-20$ Ave.

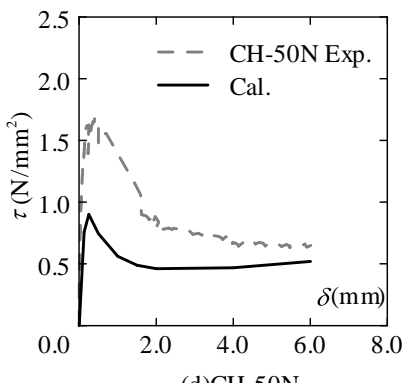

(d) $\mathrm{CH}-50 \mathrm{~N}$

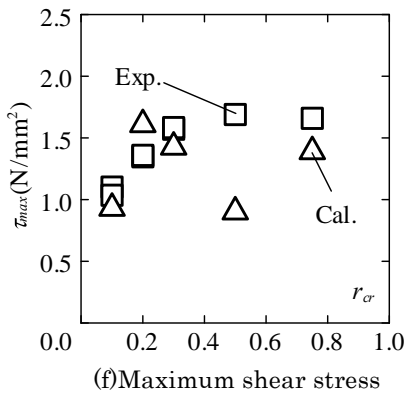

Fig. $12 \tau-\delta$ curves and maximum shear stress

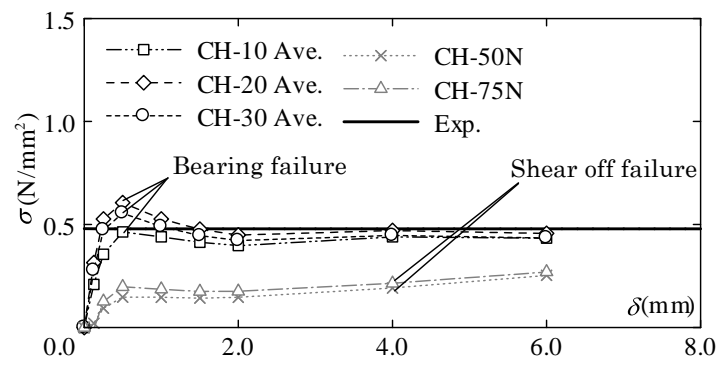

Fig. $13 \sigma-\delta$ curves

$$
\begin{gathered}
\tau=Q / A_{j} \\
\sigma=N / A_{j}
\end{gathered}
$$

Fig. 12 より， $r_{c r}$ が 0.1 0.3 の試験体では実験結果を精度よく追 跡できていることが分かる。本提案モデルでは， $r_{c r}$ が 0.2 の試験体 の方が 0.3 の試験体よりも最大応力が大きくなる結果となった。こ れは傾斜密度分布の関係で, $r_{c r}$ が 0.2 の試験体の方が, $\theta= \pm \pi / 2$ (rad.) 近傍の分布が僅かに大きくなった結果による。 $r_{c r}$ が 0.5 と 0.75 の 試験体では, 最大応力が実験值より小さくなった。前述した通り, これらの試験体は, シアオフ破壊しているが, 本提案モデルは, 微 小凹凸面の接触応力に基づく支圧破壊を対象としたモデルである。 したがって, 破壊形式の違いから, これらの試験体の実験結果を再
現できなかったと推察される。

Fig.12(f)では，横軸に $r_{c r}$, 縦軸に最大せん断応力 $\tau_{\max }$ を示してい る。実験結果を観察すると， $r_{c r}$ が大きくなるにつれ最大応力も上昇 する傾向にあるが, $r_{c r}=0.5$ を上回ると, 最大応力の差が小さくな る。さらに本提案モデルでは, 破壊形式が異なる $r_{c r}=0.5,0.75$ の実 験結果を再現できておらず，シアオフ破壊する試験体については, 別のモデルの適用が必要であると考えられる。

続いて垂直応力 $\sigma$ にいて, 解析結果と実験結果を比較する。Fig. 13 に垂直応力 $\sigma$ 一七ん断変位 $\delta$ 曲線を示す。 $r_{c r}$ が $0.1 \sim 0.3$ の試験体 では，実験值を概ね良好に追跡できる。しかしながら，破壊形式が 異なる $r_{c r}=0.5$ および 0.75 の試験体は, せん断応力と同様に, 実験 值を下回る結果となった。

以上から，支圧破壊する試験体に対しては，本提案モデルによっ て, 実験結果を精度よく再現可能ではあるが, 既存側がシアオフ破 壊するケースに対して，今後，検討を重ねる予定である。

\section{5. 結論}

著者らは，コンクリート構造物における既存躯体と補強部材の接 合面の目荒らし面を対象とし，せん断載荷実験および形状測定・分 析を行った。また，これらの実験結果および既往のひび割れ面の応 力伝達モデルを基に, 目荒らし面の力学モデルを構築し, 実験結果 への適合性について検証した。

以下に本論文で得られた知見を列記する。

1）傾斜密度分布について， $r_{c r}$ が大きくなるにつれ，ピーク值 が小さくなり， $\theta= \pm \pi / 2$ 近傍の值が徐々に大きくなった。

2) $r_{c r}=0.1 \sim 0.3$ の試験体では支圧破壊が， $r_{c r}=0.5,0.75$ の試 験体ではシアオフ破壊がそれぞれ支配的であった。

3）せん断載荷実験より，実験值と本提案モデルを比較した結 果, $r_{c r}$ が $0.1 \sim 0.3$ の試験体については $\tau-\delta$ 曲線, $\sigma-\delta$ 曲線 ともに，概ね良好に実験值を再現することができた。

4）本提案モデルは，接触応力に基づく支圧破壊を対象とした モデルであるため，シアオフ破壊する $r_{c r}$ が 0.5 以上の試験 体には，適用できなかった。

今後は，既存躯体側コンクリートの $\sigma_{B}$ をパラメータとした実験を 行い, さらにシアオフ破壊するケースについても再現できるモデル を構築することに加え, 接合部の変位場の解明についても研究範囲 を広げ，軸応力一定実験だけでなく実現象の変位場を再現した検討 を行うなど，本研究を発展させる予定である。

\section{参考文献}

1) The Japanese Building Disaster Prevention Association: Seismic evaluation and retrofit, 2017.7 (in Japanese)

日本建築防災協会 : 2017 年改訂版 既存鉄筋コンクリート造建築物の耐 震改修設計指針・同解説，日本建築防災協会, 2017 年 (2017 年改訂版第 2 刷)

2) Katori, K., Abe, T., Kubota, M., Takase, Y., Sakazaki, T., Hiwatashi. T., Murata, T., and Hirata, S.: Development of Concrete Surface Roughening Method having Minimal Vibration and Noise. Part7. Evaluation of Indirect Connection Shear Strength, Summaries of Technical Papers of Annual Meeting, Architectural Institute of Japan, Structures IV, pp.293-294, 2013.8(in Japanese) 香取慶一, 阿部隆英, 久保田雅春, 高瀬裕也, 坂崎友美, 樋渡健, 村田鉄 男, 平田誠之：低騒音・低振動の目荒らし工法の開発（その 7）耐力の検 
証, 日本建築学会大会学術講演梗概集, 構造IV, pp293-294, 2013.8

3) Tsuyoshi, M., Ishimura, Y., Sadasue, K. and Minami, K.: Study on Shear Strength of Diagonal Post-installed Anchor, Proceedings of the Japan Constitute Institute, Vol.32, pp.985-990, 2010.6

津吉真人, 石村光由, 貞末和史, 南宏一: 傾斜あと施工アンカーのせん断 強度に関する基礎的研究，コンクリート工学年次論文集, Vol.32, No.2, pp.985-990, 2010.6

4) Fenwick,R.C., Pauly,T.: Mechanisms of Shear Resistance of Concrete Beams, Journal of Structure Div., ASCE, Vol. 94, No.10, pp.2325-2350, 1968.10

5) Bazant,Z.P. and Gambarova,P.: Rough Cracks in Reinforced Concrete, Journal of Structure Div., ASCE, Vol. 106, No.4, pp.819-842, 1980.4

6) Walraven,J.C. : Fundamental Analysis of Aggregate Interlock, Journal of Structure Div., ASCE, Vol.107, No.11, pp.2245-2270, 1981.11

7) Watanabe, F., Kouno, S. and Muguruma, H.: Aggregate Interlock along a Cracked Surface and Its Modelling, Proceedings of the Japan Concrete Institute, Vol.11, No.2, pp.311-316, 1989.6 渡辺史夫, 河野進, 六車熙: ひび割れ面における骨材の噛合い作用とそ のモデル化，コンクリート工学年次論文集,Vol.11, No.2, pp.11-2, 1989.6

8) Li, B., Maekawa, K. and Okamura, H.: Contact Density Model for Stress Transfer across Cracks in Concrete, Journal of the faculty of Eng. University of Tokyo(B), Vol.40, No.1, pp.9-52, 1989

9) Bujadaham Buja: The Universal Model for Transfer across Crack in Concrete, Department of Civil Engineering, The Graduate School of The University of Tokyo, 1991.3

10) Takase, Y., Abe, T., Itadani, H., Satoh, T., Onaka, A., Kubota, M. and Ikeda, T.: Estimation Method of Horizontal Capacity of Joint Fracture for Retrofitted Frame using Disk Shear-Key - Study on Shear-Key Consisted of Steel Disk and Anchor Bolt for Earthquake Retrofitting, Journal of Structural and Construction Engineering (Transaction of AIJ), Vol.79, No.698, pp.507-515, 2014.4

高瀬裕也, 阿部隆英, 板谷貴志, 尾中敦義, 久保田雅春, 池田隆明: ディ スク型シヤキーを用いた補強架構の接合部破壊時の保有水平耐力の評価 手法-鋼製ディスクとアンカーボルトを併用した耐震補強用シヤキーに 関する研究, 日本建築学会構造系論文集, Vol. 79, No. 698, pp.507-515, 2014.4
11) Abe, T., Hiwatashi, T., Kubota, M., Takase, Y. and Katori, K. Development and Equation for Shear Strength of Cylindrical Shear-Key Applied Seismic Retrofitted Joint of Concrete Structure Study on Indirect Joints with Cylindrical Shear-key, Journal of Structural and Construction Engineering (Transaction of AIJ), Vol. 82 , No.736, pp.873-883, 2017.6

阿部隆英, 樋渡健, 久保田雅春, 高瀬裕也, 香取慶一: コンクリート構造 物の耐震補強の接合部に適用寸る円柱状シアキーの提案と耐力式の構築 一円柱状シアキーを用いた間接接合部に関する研究-, 日本建築学会構造系 論文集，Vol.82, No.736, pp.873-883, 2017.6

12) Architectural Institute of Japan: Structural Design of Precast Concrete Connection Emulating Cast-in-place Reinforced Concrete, 2002

日本建築学会 : 現場打ち同等型プレキャスト鉄筋コンクリート構造設計 指針 (案) ・同解説, 日本建築学会, 2002

13) Darwin, D. and D. A. Pecknold: Analysis of RC Shear Panels under Cyclic Loading, J. of Structure Div., ASCE, Vol.102, No.ST2, pp.355-369, 1976.2

14) Nakano, K. and Matsuzaki., Y.: Additional Method of Shear Resistances in Precast Concrete Connections, Journal of Structural and Construction Engineering (Transaction of AIJ), No.550, pp.151-158, 2001.12

中野克彦，松崎育弘：プレキャスト $\mathrm{RC}$ 部材接合面におけるせん断抵抗 要素の耐力累加方法, 日本建築学会構造系論文集, No.550, pp.151-158, 2001.12

15) Japan Building Disaster Prevention Association: External Seismic Retrofitting Manual, 2002 (in Japanese) 日本建築防災協会：既存鉄筋コンクリート造建築物の外側耐震改修マニ ユアル, 2002 年 (初版 3 刷)

\section{付録}

付 1）文献 15)において, 接合部のずれを $2 \mathrm{~mm}$ 以内に抑えて設計するように 規定されていることから，本実験では，過大地震時を想定した場合で も適切に評価できるよう,検証範囲を上記の $2 \mathrm{~mm}$ を 3 倍した $6 \mathrm{~mm}$ と している。 


\title{
SHEAR STRESS TRANSFER OF ROUGHENED CONCRETE FOR EXISTING R/C MEMBERS AND MECHANICAL MODEL BASED ON CONTACT STRESS ON LOCAL SURFACE
}

\author{
Tsubasa ISOZAKI ${ }^{* 1}$, Yuya TAKASE ${ }^{* 2}$, Takahide ABE*3, \\ Keita SAKAMOTO ${ }^{* 4}$, Takeshi HIWATASHI ${ }^{* 5}$ and Keiichi KATORI*6 \\ ${ }^{* 1}$ Grad. Student, Div. of Sustainable and Environmental Engineering, Muroran Inst. of Technology \\ (Present affiliation is Hitachi Architects \& Engineers Corporation) \\ *2 Assoc. Prof., College of Environmental Technology, Muroran Institute of Technology, Dr.Eng. \\ ${ }^{*}$ Chief, Seismic Solution Dept., TOBISHIMA Corporation \\ ${ }^{* 4}$ Chief, Seismic Solution Dept., TOBISHIMA Corporation, M.Eng. \\ ${ }^{* 5}$ Senior Researcher, Research and Develop Center, TOA Corporation, Dr.Eng. \\ ${ }^{* 6}$ Prof., Dept. of Architecture, Fac. of Sci. \& Eng., Toyo University, Dr.Eng.
}

In the joints of seismic retrofitting structures, post-installed anchors are generally used. The concrete surfaces at the joints are roughened through a chipping process using a vibration drill in order to achieve the shear force stipulated in the Japanese guidelines for the seismic retrofitting of structures. However, there are no unified rules for concrete roughening in terms of shear force or the shape of the roughened surface. On the other hand, some previous studies focused on shear stress transfer mechanisms of cracked concrete surfaces. According to these research, we can estimate the shear stresses and normal stresses interacting on the entire cracked surfaces by integrating the contact stress over the area of the entire interface. Therefore, we conducted shear loading tests, and measurements of the roughened surface were taken. We then constructed a mechanical model based on the constitutive law that describes the shear stress transfer mechanisms of cracked concrete surface.

Eight test specimens were prepared. We roughened the concrete surfaces of the eight specimens. For the test specimens, the existing member was modelled by a rectangular block with dimensions $580 \mathrm{~mm} \times 400 \mathrm{~mm} \times 200$ $\mathrm{mm}$. After roughening an area of $375 \mathrm{~mm} \times 200 \mathrm{~mm}$ centered on the concrete surface, grouting mortar of dimensions $375 \mathrm{~mm} \times 200 \mathrm{~mm} \times 200 \mathrm{~mm}$ was cast on the surface.

The test parameters considered here were the roughed concrete depth as well as the ratios between the roughened area and the surface area $(0.10,0.20,0.30,0.50$, and 0.75$)$. We took measurements of the roughened surface using laser displacement sensors. The measurement intervals were set to $0.04 \mathrm{~mm}$ in the $x^{\text {-direction and }}$ $0.5 \mathrm{~mm}$ in the $y$-direction. For the shear loading tests, we controlled the shear displacement and applied repeated cyclic loading. The constant normal stress was set to a constant value of $0.48 \mathrm{~N} / \mathrm{mm}^{2}$.

We constructed a mechanical model of the roughened concrete surface using the Bujadaham model (Bujadaham 1991). This model takes into account the stress transfer mechanisms of the cracked surface. The angle density function $\Omega(\theta)$ in the Bujadaham model was set as $\Omega(\theta)=0.5 \cos \theta$. However, it was not known whether or not we could use this defined angle density function for the roughened concrete surface. Therefore, we evaluated $\Omega(\theta)$ using the three-dimensional data obtained from the shape measurements of the roughened surface. Additionally, we proposed $\Omega(\theta)$ using the shape measurement results. The test and calculation results were in agreement. However, the contact stress in the Bujadaham model adopted an elasto-plastic model, we newly constructed the model between contact stress and contact displacement for the roughened concrete surface. In the proposed contact stress model, the stress softening behavior in the roughened concrete was considered.

We constructed a mechanical model representing the roughened concrete surface and compared the experimental and analytical values. By using a constitutive equation that expresses the shear transfer mechanism of a cracked surface, and that takes into account the contact stress and friction on the local surface, the shear and vertical stresses of specimens with a roughened concrete area ratio of up to 0.3 can be evaluated. However, for specimens with a roughened concrete area ratio of 0.5 or 0.75 , the shear and vertical stresses are underestimated. Thus, we were not able to express the specimens of shear failure modes using the proposed model. This problem will be a focus of future research. 